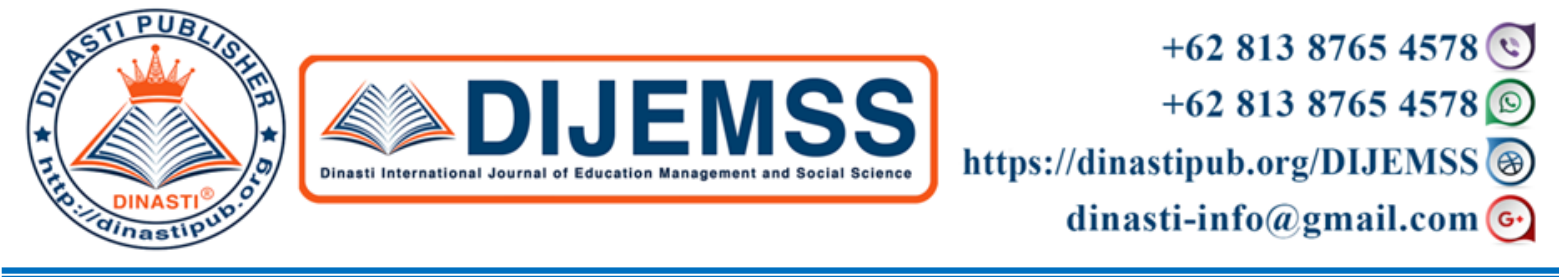

\title{
REVIEW OF GOOD CORPORATE GOVERNANCE (GCG) APPLICATION IN OPERATIONAL ACTIVITIES IN PT BANK CENTRAL ASIA, Tbk
}

\section{Mesra Lindawati}

Mercu Buana University, Jakarta, Indonesia

ARTICLE INFORMATION

Received: $2^{\text {nd }}$ May 2020

Revised: $25^{\text {th }}$ June 2020

Issued: $22^{\text {th }}$ August 2020

Corresponding author:

First Author

Email:

mesra.echa@gmail.com

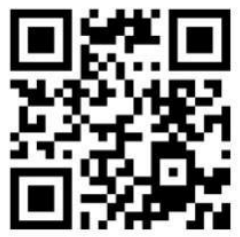

DOI:10.31933/DIJEMSS
Abstract: The need to apply the principles of good corporate governance in companies felt very strong in the industrial banking. External and internal conditions in banking are getting more complex. The risks of banking business activities are more diverse. Given the situation, the need of healthy company practices in the banking field. Increases. BCA is a banking financial services company that was established with the aim to participate in advancing the Indonesian economy. As a banking financial services company that relies on customer trust, the management of the company carries out operations with the principle of prudence. One of the keys made by PT Bank Central Asia, Tbk to face the increasingly stringent challenges of the Indonesian banking sector is to carry out good corporate governance. This is done so that the Bank can consistently maintain customers, shareholders, and other parties trust.

Key Words: Good Corporate Governance, Banking, Policy Strategy

\section{INTRODUCTION}

\section{Background}

The crisis that struck Asian countries that began in 1997 greatly affected Indonesia's domestic conditions. As a result of the crisis, Indonesia experienced changes in almost all aspects of life such as social, cultural, political, security, and economic aspects. In the era of the crisis that we know, either small or large companies experienced failure and stopped their operational activities. As a result of security and economic systems instability, investors trust is decreasing, monitoring systems aren't running as they should, corruption, collusion, and nepotism grew fertile causes stock investment and activities of the economy experiencing deflation. 
The economic strength of a country cannot be separated from the existence of finance banking institutions. In the economic activities, bank functions as an intermediary activity traffic system of payment and as an institution provider of funds for the activities of development. The crisis that occurred in 1998 provides a lesson that is important for the government, employers, and communities that managing a business must be conducted with good principles to manage it well. As it is known, the crisis in 1998 led many banks to close down and liquidate because of a shortage of liquidity. This is because the bank owners did not run the managerial well, the principle of prudential banking did not run well and supervision authorities monetary were extremely weak.

The term Good Corporate Governance (GCG) began to be introduced in Indonesia since the year 1999. The introduction of GCG began after the government formed a committee of the National Policy Governance (NCG). Other than the growing economy and to accommodate the interests of world business, in the year 2006 the NCG then issued a revised provision of GCG to be used as guidelines for the general application of good corporate governance in Indonesia.

Implementation of GCG is important to build trust as the impact of the effects of globalization and free trade that gave a change that is so great about the life of the economy in general and in particular the impact on the world of business.

The application of GCG is expected to encourage the creation of an efficient, consistent and transparent market. In principle, the successful implementation of GCG require support that is stronger than 3 (three) elements, namely:

1) Governments with a device and acted as a regulator

2) The business world that acts as a market participant

3) The general public as users of products and services.

Be aware that the implementation of GCG up till now cannot accommodate all the interests due to a very wide scope GCG across various sectors. However, the core of the implementation of corporate governance policies (GCG) is intended so that the relevant parties that play a role in running the company, namely: shareholders, commissioners, committees, directors, work unit leaders and employees can better understand and carry out the role and functions in accordance with their respective authorities and responsibilities.

PT BCA, Tbk is a banking financial services company that was established with the aim to participate in advancing the Indonesian economy. As a banking financial services company that relies on customer trust, the management of the company is handled very carefully.

One of the key point that was done by PT BCA, Tbk to face the increasingly stringent challenges of the Indonesian banking sector is to carry out good corporate governance. This is done so that the Bank can consistently maintain the trust of customers, shareholders and other stakeholders.

\section{Problem Formulation and Problem Limits:}

Based on the background of the problem which has been described above, it is concluded as follows: As part of the business actor that is involved in the role of organizing the economic activities in Indonesia, authors conclude the problem as follows:

1) As part of the business actor that is involved in the role of organizing the economic activities in Indonesia, did BCA run the principles of Good Corporate Governance (GCG) in developing their business?

2) What are the benefits derived from the application of GCG?

Writer limits the scope of the application of the principles of Good Corporate Governance (GCG) only in Bank Central Asia Tbk. 


\section{Purpose:}

The purpose of writing this is to fulfill Ethical Business course task and to know: The application and implementation of the principles of Good Corporate Governance in PT Bank Central Asia Tbk.

\section{LITERATURE REVIEW}

\section{Definition of Good Corporate Governance:}

Good Corporate Governance is derived from the word governance, meaning the process of managing economic and social resources that involves the government in an activity. While in economics, GCG is defined as the process to achieve the success of business that is carried out with democracy, transparent and accountability.

\section{Definition of Good Corporate Governance from experts:}

GCG have very spacious aspects, the experts give a definition that is different among them and as follows:

1. Governance according to Azhar Kazim (1993):

Governance is the process of managing life aspects such as social, economic, political, and others in a country as well as the utilization of natural resources, financial and human in a way that is in accordance with the principles of fairness, efficiency, transparency also accountability.

2. According to Sukrisno Agoes (2011);

Good Corporate Governance (GCG) is a managing system that regulate the relationship between the role of the board of commissioners, the role of directors, stakeholder and other parties. A good company managing system are known as a process that is transparent to the decision goal of the company, the achievement, and assessment of performance.

3. According to Amin Widjaja Tunggal (2013):

GCG is a system that organize, manage, and supervise the business control process to increase the value of shares as well as the attention of stakeholders, employees and the public.

4. The Indonesia Institute for Corporate Governance (IICG) states that:

"Corporate governance is the set of mechanisms that directs and controls companies so that the operational activity runs in accordance with the expectations of other parties (stakeholders).

5. According to the World Bank (World Bank):

Corporate Governance is a set of law, regulations, and rules that must be met which can push the performance of companies resources with efficient, produce long-term economic value continuously to the holders of shares as well as the public.

6. Meanwhile, according to the Regulation of Bank Indonesia (PBI) number 8/4 / PBI / 2006, GCG Banking is a bank managing system that applies the principle of transparency, accountability, liability, independence, and fairness.

From the explanations above, we can conclude that good corporate governance is a system and structure of company management that are carried out for the purpose of increasing the value of shareholder value and also accommodate parties that are interested in the company (stakeholders), such as suppliers, creditors, associations of business, employees, consumers, government, and society . 


\section{GCG Objectives}

The application of GCG has the following objectives:

a) To be able to develop and increase company value.

b) In order for companies to maximize resource management and risks effectively and efficiently.

c) Increase responsibility and discipline of companies for the sake of keeping the interests of the companies shareholders and stakeholders.

d) To increase the contribution of companies (especially government companies) to the national economy.

e) Increase national investment; and

f) Supporting privatization program of government companies.

\section{The role of GCG For Bank}

The bank is a financial institution that has the main task of collecting and distributing funds from and to the public. Main product of bank is managing the funds that are entrusted by the public /customers to the bank. The principle of the bank's operational activity is trust . In order to maintain the trust, the implementation of GCG to the bank is a way to build the trust of the customers, the community, and the international world.

The application of GCG will affect the ethical codes of banking which have been an important factor in carrying out day-to-day operational activities of the bank. A good company managing system is implemented by running the functions of the company based on the principles of good management with a process that is transparent based on the decision of the goal of the company, namely: companies achievement performance and companies assessment performance in order to provide good quality service continuously.

In general, the company can be said to be successful if the existence and activities last long and the benefits can be felt by shareholders, employees, governments, and communities around. In order to maintain the trust of society towards the company, then the individuals who play a role as implementers should be able to carry out its functions with full responsibility in accordance with duty which is charged to him/her.

\section{Principles of corporate governance according to the Committee of National Policy Governance (NCG)}

Below will be explained in detail the principles of good corporate governance:

\section{1) Openness (Transparency)}

The openness is a principle that guarantees all the stakeholders can access information about the company concerning the organization of activities, policies and results of the achievement. Companies openness to information require elements which can be compared. Completeness of the information that is received will facilitate the stakeholders to do an evaluation to take a decision on the existence of the company and its activities. Information in banking includes, the company's strategies and plans, finance, the composition of the company's management, the supervision system, the implementation of the compliance system, and the applied risk management. However, not all information can be given openly, data that holds client information cannot be given because of the bank secrecy regulations. 


\section{2) Accountability}

Accountability is an obligation to report the whole effort and achievement and are liable to the success or failure of the company. Therefore, bank officer in carrying out their duties are required to be able to make the work program and determine the duties and responsibilities of each unit clearly based on the vision, mission, and strategy of the company. In order for the accountability principle to be implemented, deciding and placing the right employee to occupy the position in accordance with his/her competence becomes important. Companies must apply thigh discipline in order to carry out their duties with both reward and punishment system that is clear and transparent.

\section{3) Responsibility}

Companies bear the burden of the task that has been determined by the stakeholders, therefore to achieve success, in running their duties, banks should ensure the principle of carefulness prudence (prudential banking practices) implemented consistently. Operational activities must be carried out by standard operations which are supported by the regulation and systems that are clear and appropriate to the regulations that apply. In addition to that, the bank is required to reflect the image of a good company and have awareness of the environment around and is sensitive to bear social responsibility.

\section{4) Independence}

As it is known that every stakeholder in the company has different interests, therefore, in carrying out operational decisions taken by the management of the company must be done freely and objectively and free from pressure from any party. This principle is carried out so that the strategy could avoid dominance and influence of one or a portion of shareholders and thus the conflict of interests of shareholders can be avoided.

\section{5) Fairness}

In order to fulfill the stakeholders interests with the right proportion, in carrying out its activities, board of the bank should pay attention to act based on the principles of fairness and equality so as to thereby not to harm any parties interests. Stakeholders should be given the right of access to provide feedback or suggestion on the performance of the bank based on the information that is received through the principle of openness.

Banking company is a company that is based on trust. The existence of the bank in the economic system becomes very important. Therefore, to ensure the measuring level of success of operational activities are successful, Bank Indonesia requires each bank agency to do a self -assessment with eleven factors and report the results. Those factors are as follows:

a) The application of duties and responsibilities of the Board of Commissioners

b) Duty execution and responsibilities

c) Committees and work unit that serves to run internal control to execute their duties well.

d) To assist smoothing the process of supervision, the Board of Commissioners formed a committee, and the task of controlling by the Board of Directors is supported by;

e) Forming units of work that perform the function of control such as internal audit work unit, compliance work unit, and Bank risk management work unit.

f) Implementation of compliance, internal auditor, and external auditor functions

g) Implementation of risk management, including internal control systems; 
h) Provision of funds to the relevant party and provision of large funds with the provisions regarding the Maximum Limit Credit Granted for General Bank.

i) Run banks strategical plan, which includes corporate strategical plan, as business plan.

j) Financial and non-financial bank situation report that is transparent.

k) Bank strategical plan (PBI number 8/14 / PBI / 2006)

\section{RESEARCH METHOD}

In completing this task, the author obtained data used via Internet media and websites, namely by reading references and journals that relate to the issues that are discussed in this task. The author also obtained data from the author's knowledge and experience from the work environment because the topic was about the application of GCG in the company where the writer works.

\section{RESULT AND DISCUSSION}

\section{Company Profile:}

Founded in 1957, has been present in the midst of society and developed into one of the largest private banks in Indonesia. For more than sixty years of BCA does not cease to innovate and deliver a variety of financial solutions that are in accordance with the needs of the customer.

By giving various forms of services and quality products that are appropriate, the financial solution of BCA always be present to support the financial planning of individuals and develop client business.

Supported by the strength of the inter- branch service network and the breadth of the Automated Teller Machine network, as well as other electronic banking networks, all customers will find it easy to conduct banking transactions at BCA.

In accordance with our commitment, ' Always by Your Side' will always try to maintain the trust and expectations of all customers and all stakeholders.

The hope to be able to always win the trust of customers to provide solutions best for the needs of financial is an honor and pride for BCA. In accordance with the Decree of the Minister of Finance of the Republic of Indonesia no. 42855 / U. M.II dated March 141957 concerning licenses to conduct bank business.

\section{Implementation of the BCA Strategy Policy}

BCA ensures the principle application of good corporate governance in the entire level of organization. The implementation of GCG is based on the values of transparency, accountability, responsibility, independence, and fairness. The implementation of GCG at all levels of BCA organization has been adjusted to the regulations that apply in the country and further harmonized with the provisions of the ASEAN Corporate Governance Scorecard.

In the year 2018 the Bank enhanced the guidelines for GCG in line with the adjustment to the provisions of the latest regulator.

BCA strategic policy are in tune with Indonesia's dynamic changes in condition of the economy and development of banking sector. Various activities of businesses run by applying the principle of caution and attention to the level of liquidity that is increasingly 
stringent, quality credits which are always maintained, and the increasing rate of interest trend.

With excellence in banking transaction system and supported by the service finances that are comprehensive to the client, fund demand deposits and savings (Current Accounts and Savings Accounts - CASA) continued to increase and still provide major contributions to BCA's third-party total amount funds.

Doing the management of rate of interest on deposits by adjusting the rate of interest credit with caution, because BCA channel the credit facility to the public with the implementation of risk management with discipline.

Nowadays technology advances very quickly, this affects society needs on a variety of products and facilities that are in accordance with the character of the customer that prioritizes ease and speed of transaction, this encourages companies take advantage of the opportunities that exist to develop service-based digital, method of online payment, cashless payment, and various facilities in the field of e-commerce. Digital services felt to be very helpful to the community while responding to the need for financial facilities that are able to adapt to technological advancements.

Meanwhile, BCA still extend the office branch, it is done because branch is still deemed important as one of the means to keep maintain the relationship with the customers who still require services that cannot be done via digital banking.

In order to maintain the quality of the implementation of GCG, Bank periodically perform self-assessment of the implementation of GCG either as individuals or as integrated with child entities. In the year 2018 the results of BCA's self-assessment to the implementation of good corporate governance in companies produce rankings with the title of 'Very Good' either as individuals or as integrated. With a good application of corporate governance, the Bank can maintain confidence of the stakeholder's interests and support the continuity of business enterprise continuity.

BCA is involved in various activities of social community (Corporate Social Responsibility - CSR) and focused to contribute in tangible for the people of Indonesia. In the implementation of CSR programs, the Bank worked together with leading institutions that are experienced and competent in fields such as WWF, UNICEF, Indonesia Red Cross and several leading universities in Indonesia. BCA's social event remains focused on aspects of education and culture, health and sport, as well as the empowerment of the public community.

Implementation of consistent GCG becomes a choice in order to maintain the trust of our customers, stakeholders, and other parties. To ensure GCG can be applied, the entire lineup of directors and employees carry out their duties based on the principle of good corporate governance and in order to continue to run standard application of good corporate governance perfectly, in addition to following the rules of Bank Indonesia, the FSA and other government provisions, a standard that is applied by BCA also refers to Asean Corporate Governance Scorecard (ACGS) .

In order to form a clear structure and reflect the application of the principle of check and balance as well as a good internal control system, the Corporate Governance Structure at BCA consists of: 
1. General Meeting of Shareholders (GMS).

2. Board of Commissioners.

3. Directors.

4. Committees at the bottom of the Board of Commissioners are: Audit Committee, Risk Monitoring Committee, Remuneration \& Nomination Committee, and Intergrated Governance Committee.

5. Executive Directors Committees namely: Asset \& Liability Committee (ALCO), Management Risk Committee, Integrated Management Risk Committee, the Policy Credit Committee, the Committee of Credit, Technology Information Steering Committee, the Civil Case Consideration Committee.

6. Corporate Secretary.

7. Risk Management work unit, Compliance Unit, Legal Unit, Internal Audit and Internal Control units.

In order to improve the effectiveness of whistleblowing application system, in detecting fraud or violations that were carried out by the internal of the company, Bank has been implementing a policy related to the whistleblowing system.

Now BCA has a unit work that is in charge of dealing with the effectiveness of the implementation of whistleblowing systems, which are responsible to the President Director and has a relationship to communicate and report it directly to the Board of Commissioners.

\section{Objective Implementation of GCG at BCA:}

The application of good corporate governance by industrial banks are felt to be very necessary, it is because of a very complex internal and external bank situations. The need of good corporate governance application is required because the risk of activity of bank business are increasing.

BCA are getting more aware of the importance of applying the principles of good governance which is aimed to improve the results of the performance of the bank, protect all the interests of stakeholders and adherence to laws that apply and the application of the values of ethics that applies in common industrial banking.

In addition, the goal of applying GCG at BCA is to support the vision of the Bank, to be the "Bank of choice for the community, which plays a role as a pillar of important economies of Indonesia" and supports the mission of the Bank, namely: Build institutions that excel in the field of payment settlements and the finance solution for businesses customers and individuals, to understand the diverse needs of customers and provide appropriate financial services to achieve optimal customer satisfaction.

The setting and implementation of good corporate governance requires a commitment from the entire range of the company up to the top management. Starting from determining the company's core policy (strategic policy) and the code of ethics that should be met and obeyed by all parties. In the world of banking in Indonesia, the most important factors that are used as a cornerstone in the implementation of good corporate governance is the application of ethical business in the enterprise.

Good corporate governance which became one of the keys to facing a competitive competition in the sectors of banking in Indonesia. BCA consistently strives to maintain the 
trust of its customers, shareholders, and other stakeholders by upholding good corporate governance carried out by all board of directors and employees to ensure healthy company performance, especially in the face of competitive banking service that enters the ASEAN Economic Community.

The foundation and good corporate governance become substantial to gain the trust of stakeholders. Until now, BCA has consistently implemented the company's values as an effort to increase and maintain the trust of the Indonesian people, which in turn will give birth to a positive and growing business and always maintain good performance.

With the application of good governance, BCA can maintain the trust of stakeholders and support the long-term sustainability of the company's business.

\section{Awards obtained:}

- In the year 2018 the results of self-assessment on corporate governance entered into a category rating I (Very Good).

- BCA received the 'Most Trusted Company' award from the Indonesian Institute for Corporate Governance (IICG) and SWA Magazine and the 2018 'Best Right of Shareholders' award from the Indonesian Institute for Corporate Directorship (IICD)

- Top 50 Biggest Market Cap and Mid Cap of Public Listed Companies in Indonesia The 11th IICD Corporate Governance and Award 2019 Oct 09, 2019

\section{CONCLUSION AND SUGGESTION}

\section{Conclusion:}

Based on the description of the discussion above it can be concluded that the strength of the economy of a country is determined by the stability of the economic, political, and security system. At the time of the crisis in 1998 many companies and banks were closed, the collapse of the bank at that time was not solely due to external factors but also caused by a bad corporate management system. The company's management does not implement the principles of good corporate governance.

Banks are one of the main pillars of a country's economic strength, the success of bank operations is influenced by two interrelated factors namely internal and external factors. Internal factors are how bank management activities are carried out with good corporate governance, in general the success and failure of a company or bank can be controlled by the company's management in accordance with the company's vision, mission and strategy.

While external factors are situations or circumstances that originate from outside the company that affect the failure of a bank that is beyond the control of the company, the causes include political, economic and security stability. External factors require the role and intervention of the government through regulations or regulations created as a controlling tool.

BCA is one of the largest private banks that has contributed to the economy in Indonesia. Operational activities are the spearhead of all company activities. Recognizing the important role played by BCA in its position as a financial institution, BCA is seriously and consistently implementing Business Ethics in its operational activities. 
Banks are required to succeed in their business, given the bank's business is trust, the company's operations must be carried out with good governance (GCG) in accordance with applicable regulatory mechanisms. GCG is an important element for a company to ensure its business runs well so that its customers are loyal to the company. Thus, the sustainability of the company will run well so that the company's contribution can be felt by shareholders, employees, customers and the community.

\section{Suggestions:}

Advances in technology that are developing rapidly greatly affect business activities significantly. With the change in technology, banking operations will also experience changes, on the other hand this regulation is sometimes not offset by changes in applicable laws and regulations. Therefore, in dealing with such situations, BCA must be able to adjust in carrying out its operational activities in creating new innovations in accordance with its vision and mission.

Employee's knowledge and ability to apply regulations that are in accordance with the legislation related to good corporate governance is not evenly distributed, especially at the level of staff who carry out operations. Therefore, the work unit leaders who become leaders must be briefed through training that is carried out consistently so that it will minimize errors that may occur and ultimately to the potential for deviations or violations of activities that will harm all parties can be avoided.

In order to anticipate adverse effects due to misuse of GCG caused by external factors and beyond the control of the company's management, BCA needs to think of more effective ways to increase employee knowledge to follow and understand the changes that occur, the ability to understand the development and changes in regulations, especially at the level of implementing staff will play a big role when the company faces operational problems.

\section{REFERENCES}

Eunuch, Azhar . Measurement of Effectiveness in Organizations . Center for Inter- University Science Sciences Social University of Indonesia. Jakarta. 1993

Ali, Hapzi.2020. Business Ethics \& GG Concepts and Theories of Business Ethics. Mercu Buana University. Jakarta.

Agoes , Sukrisno . 2011. Business and Professional Ethics . Jakarta: Salemba Empat

Amin Widjaja Tunggal. 2013. Internal Audit and Corporate Governance. Jakarta: Harvarindo

FCGI. 2008. The role of the board of commissioners and audit committee in the implementation of corporate governance Volume II. Jakarta: Citra Graha .

Bank Indonesia. 2006. Bank Indonesia Regulation Number 8/14 / PBI / 2006 Amendment to Bank Indonesia Regulation Number 8/4 / PBI / 2006 concerning Implementation of Good Corporate Governance for Commercial Banks .

Prasetyantoko , 2008. Coporate Governance: Institutional Approach , Gramedia, Jakarta.

National Governance Policy Committee (KNKG). 2006. General Guidelines for Good Corporate Governance in Indonesia. Indonesia: KNKG 
http://prasko17.blogspot.com/2012/04/peng understanding-target-pr principle-good.html https://www.slideshare.net/WahyuNorM/2-be-gg-wahyu-nor-maryono-hapzi-ali-papanapangcg-pada-pt-askrindo-persero-universitas-mercu-buana-2018

https://nanangfirmansyahblog.wordpress.com/2017/12/18/be-gg-nanang-firmansyah-hapziali-governance-rating-universitas-mercu-buana-2017/

https://www.bca.co.id/id/About-BCA

https://www.bca.co.id/about-bca/tata-management-

company/ /media/Files/gcg/2019/20190313-B-Report-Management 